\title{
SANO95.2813C \\ CONF. $960513--14$ \\ CHARACTERIZING (RATING) THE PERFORMANCE OF LARGE PHOTOVOLTAIC ARRAYS FOR ALL OPERATING CONDITIONS
}

\author{
David L. King \\ Sandia National Laboratories \\ Albuquerque, NM 87185-0752
}

\author{
Peter E. Eckert \\ Arizona Public Service Company \\ Phoenix, AZ 85072-3933
}

\begin{abstract}
A new method has been developed for characterizing the electrical performance of photovoltaic arrays. The method provides both a "rating" at standard reporting conditions and a rigorous yet straight-forward model for predicting array performance at all operating conditions. For the first time, the performance model handles the influences of irradiance, module temperature, solar spectrum, solar angle-of-incidence, and temperature coefficients, in a practical way. The validity of the procedure was confirmed during field testing of a $25-\mathrm{kW}$ array recently installed by Arizona Public Service Company. This paper describes the characterization procedure, measured array performance, and the predictive model.
\end{abstract}

\section{INTRODUCTION}

The U.S. photovoltaic industry is rapidly growing, off-grid and international markets are expanding, and the interest of utility companies is reemerging. There are documented procedures for measuring the performance of photovoltaic modules and arrays $[1,2]$. So, why do we need a new method for characterizing the performance of arrays? Because the current methods are not versatile enough or accurate enough to meet current system engineering requirements. The current ASTM method [1] has served the industry well, but is best suited for module performance measurements at only one operating condition. It doesn't translate well to other operating conditions, doesn't address all factors involved in field ratings, and is often no better than $\pm 10 \%$ accurate when applied to arrays. The limited versatility and accuracy of the ASTM method led utilities to define what they consider a more practical procedure [2], but it too has limitations. The limitations of rating procedures have complicated the procurement process for DOE-supported utility applications such as PVUSA [2] and TEAM-UP [3]. "Performance penalties" used in utility procurement processes to insure that power specifications are met have been less effective than desired. Recently, system analysts have developed a new "performance index" providing the ratio of actual power to predicted power on a real-time basis; but the value of the index is limited by the accuracy of the predictive model used for the array [4]. Data acquisition systems are used to monitor performance and to provide remote troubleshooting capability; but currently up to $15 \%$ loss in output

This work supported by the U.S. Department of Energy under contract DE-AC04-94AL8500. goes undetected due to limitations of predictive models. In addition, almost ten years of system monitoring has been required before reliability analysts can confidently say that power output has degraded by 1 to $2 \%$ per year [5]. Thus, the commercialization and expansion of the photovoltaic industry is currently being impeded by inadequate array characterization methods.

The ideal characterization method should provide accurate array performance parameters and good predictive ability for all operating conditions. Working toward this ideal, a new straight-forward method has been developed by Sandia National Laboratories.

\section{CAROL SPRING MOUNTAIN ARRAY}

The photovoltaic array on Carol Spring Mountain is part of a hybrid photovoftaic/diesel power system purchased by Arizona Public Service Company. The system powers microwave, cellular phone, and television communications equipment for a number of customers. The photovoltaic array installed in July 1995 is composed of ninety ASE Americas modules (ASE-300-DG/50). The nominally $300-\mathrm{W}$ modules are connected in 15 parallel strings of 6 modules each, and are mounted at a $35^{\circ}$ tilt.

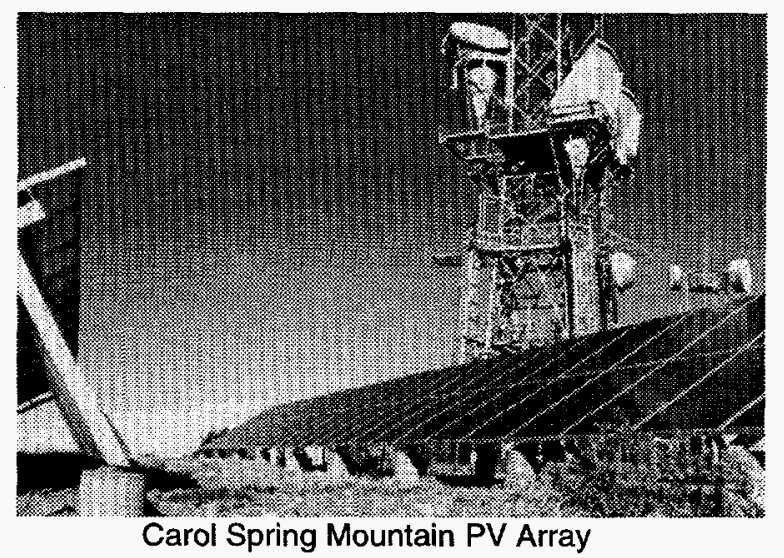

\section{PERFORMANCE CHARACTERIZATION PROCEDURE}

The procedure used for rating the Carol Spring Mountain array was based on outdoor test methods developed at Sandia for the comprehensive performance characterization of individual photovoltaic modules. Performance characteristics for modules identical to those in the Carol Spring Mountain array were measured at Sandia 


\section{DISCLAIMER}

Portions of this document may be illegible in electronic image products. Images are produced from the best available original document. 
and used in characterizing the array's performance. Specifically, the characteristics used were: temperature coefficients for short-circuit current $\left(l_{\mathrm{sc}}\right)$, maximum power current $\left(I_{m p}\right)$, open-circuit voltage $\left(V_{o c}\right)$, and maximum power voltage $\left(V_{\mathrm{mp}}\right)$; the influence of solar spectrum (absolute air mass) on $\mathrm{I}_{s c}$; and the influence of solar angle-of-incidence (AOI) on both module $\mathrm{I}_{\mathrm{SC}}$ and plane-ofarray $(P O A)$ irradiance measurements.

Table 1 gives the average temperature coefficients measured at Sandia using six different ASE-300-DG/50 modules. The module coefficients and the series/parallel configuration of modules in the array were used to calculate the array temperature coefficients. The use of separate temperature coefficients at the maximum power condition is unique to the Sandia procedure. Other procedures typically use only $I_{s c}$ and $V_{o c}$ coefficients and attempt to compensate for differences at the maximum power condition in a less direct manner [1].

Table 1. Temperature Coefficients

\begin{tabular}{|c|c|c|}
\hline Coefficient & ASE Module & CSM Array \\
\hline $\mathrm{d} l \mathrm{sc} / \mathrm{dT}\left(\mathrm{A}^{\circ} \mathrm{C}\right)$ & 0.0068 & 0.103 \\
\hline $\mathrm{d} \mathrm{mp}_{\mathrm{m}} / \mathrm{dT}\left(\mathrm{A} /{ }^{\circ} \mathrm{C}\right)$ & 0.0021 & 0.032 \\
\hline $\mathrm{d} \mathrm{V}_{\mathrm{oc}} / \mathrm{dT}\left(\mathrm{V} /{ }^{\circ} \mathrm{C}\right)$ & -0.231 & -1.39 \\
\hline $\mathrm{dV} \mathrm{mp} / \mathrm{dT}\left(\mathrm{V} /{ }^{\circ} \mathrm{C}\right)$ & -0.240 & -1.44 \\
\hline
\end{tabular}

The fact that the current from a solar cell is influenced by the spectral distribution (spectrum) of sunshine is common knowledge to people familiar with photovoltaic technology. However, the magnitude of this effect and the real significance of the effect on daily or annual energy production is not well understood or quantified. Atmospheric researchers are quick to point out that the solar spectrum is influenced by a large number of variables including: air mass, precipitable water, turbidity, clouds, dust, smoke, other aerosols, ground albedo, etc. [6]. Nonetheless, module testing at Sandia has shown that, for clear sky conditions, the influence of solar spectrum can be adequately addressed by considering only the absolute air mass. The term "absolute air mass" refers to the path length that sunlight traverses through the atmosphere, which varies with time of day [7].

In our method, the influence of solar spectrum on array performance is characterized with an empirically determined relationship. Fig. 1 shows the relative shortcircuit current from an ASE-300-DG/50 module as a function of absolute air mass, as measured at Sandia. A polynomial fit to these data gave the "AMa-Function" which was later used in analyzing the performance of the Carol Spring Mountain array. The data in Fig. 1 were measured with the module on a solar tracker normal to the sun; the $\mathrm{I}_{s c}$ was translated to $50{ }^{\circ} \mathrm{C}$, normalized to $1000 \mathrm{~W} / \mathrm{m}^{2}$ using an Eppley PSP pyranometer, and divided by the value at $A M a=1.5$. For clear sky conditions, the AMa-Function has been found to be repeatable within about $2 \%$ from day to day and month to month, particularly in the AMa range from 1 to 4 which contains the majority of the sun's energy.

The angle at which sunlight strikes an object is referred to as the "solar angle-of-incidence" or AOI. In order to accurately characterize the performance of a photovoltaic module or array, the influence of AOI must be addressed in two ways. First, the POA irradiance measurements must be corrected using an AOI-dependent pyranometer calibration. Second, the array has an AOIdependent optical behavior that can be measured and used to improve the analysis of measured performance.

The unique characteristics of pyranometers used for making solar irradiance measurements are discussed elsewhere [8, 9]. Understanding these characteristics, which can introduce time-of-day dependent errors of over $10 \%$, is crucial to obtaining an accurate array performance rating. The accuracy of the rating is directly related to the accuracy of the irradiance measurement. The Eppley pyranometer used at Carol Spring Mountain was selected for its stability and calibrated as a function of solar angle of incidence. By doing so, the uncertainty in POA irradiance measurements was reduced to less than $\pm 3 \%$.

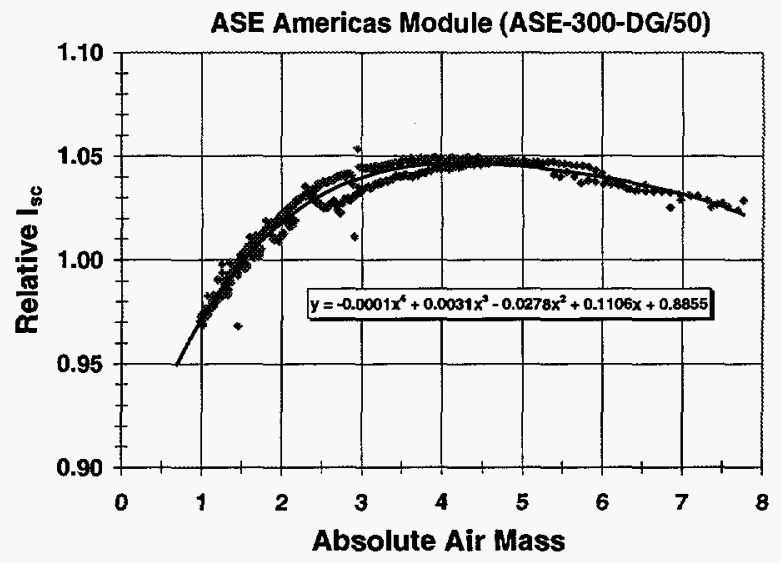

Fig. 1. "AMa-Function" giving influence of absolute air mass on $\mathrm{I}_{\mathrm{sc}}$ from ASE-300-DG/50 modules.

Like the influence of solar spectrum, solar angle-ofincidence is time-of-day dependent, and it affects the $I_{s c}$ from a PV array in two ways. The first way is familiar to solar enthusiasts as the "cosine effect." The "cosine effect" is independent of the PV technology used, and depends on only $\mathrm{AOI}$. For example, at $\mathrm{AOI}=60^{\circ}$ the cosine effect reduces $I_{s c}$ by one half. The second way $I_{s c}$ is affected is dependent on the array being evaluated; it is caused by the optical behavior of the array materials located between the sun and the cells in the array.

For typical flat-plate modules, the dominant contributor to the AOI-dependent "optical" effect is reflectance from the glass front surface. This reflectance increases significantly for $\mathrm{AOI}$ greater than about $\mathbf{5 0}$ degrees. Fig. 2 illustrates the "optical effect" measured at Sandia for an ASE Americas module. A polynomial fit to the relative $I_{S C}$ data gave an "AOI-Function" that was used at Carol Spring Mountain to remove the AOI-dependent "optical" influence. Measurements of the combined influence of optical and cosine effects are also shown in Fig. 2. The magnitude of the effects shown represent an upper limit, but are typical of the effects present under clear sky conditions. The opposite extreme occurs for overcast 
skies with perfectly diffuse illumination where $\mathrm{AOI}$ would have no influence whatsoever on $I_{\text {sc. }}$.

Finally, their are two basic premises associated with the new Sandia method. First, the $I_{s c}$ from a cell, module, or array is a very predictable function of POA irradiance (usually a linear relationship), after the influences of solar spectrum, $A O I$, and temperature have been accounted for. Second, the $I_{m p}, V_{m p}$, and $V_{o c}$ are well behaved parameters when described as functions of $I_{\text {sc }}$ and cell temperature $\left(T_{c}\right)$ only. Outdoor testing of a wide variety of commercial modules at Sandia has shown these premises to be near universally valid. As a consequence, the performance characterization of an array becomes simply a matter of determining the short-circuit current, $I_{s c o}$, at an arbitrary "reference operating condition," and then relating the other performance parameters to this reference. The reference condition chosen can be site and/or technology specific. The reference operating condition chosen for the Carol Spring Mountain array was the following:

Plane-of-array $(P O A)$ irradiance $=1000 \mathrm{~W} / \mathrm{m}^{2}$

Absolute air mass $(\mathrm{AMa})=1.5$

Solar angle-of-incidence $(\mathrm{AOI})=0$ degrees

Cell temperature $\left(T_{c}\right)=50^{\circ} \mathrm{C}$

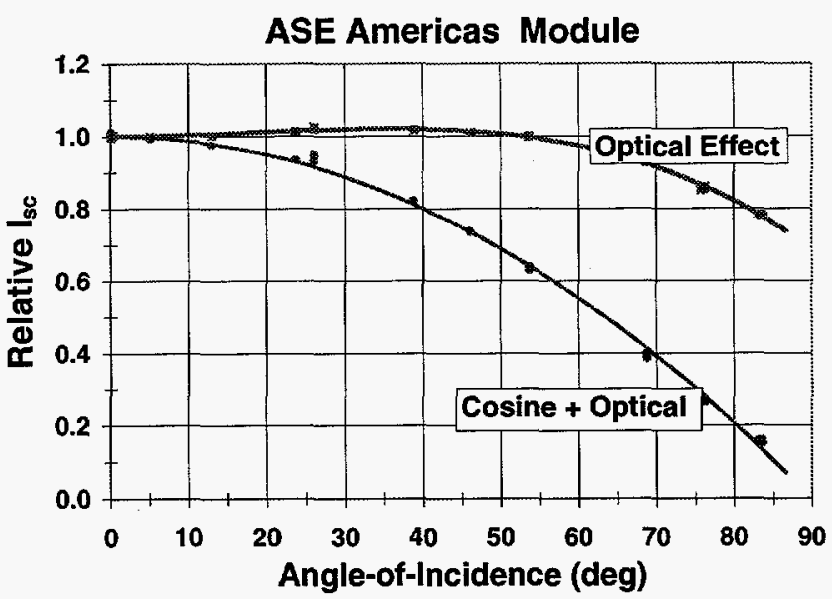

Fig. 2. "AOI-Functions" giving influence of solar angle-ofincidence on $I_{s c}$ from ASE-300-DG/50 modules .

\section{MEASURED ARRAY PERFORMANCE}

Current-voltage (I-V) curves were measured for Carol Spring Mountain array using a DayStarTM DS-100 curve tracer. The measured I-V curves were recorded at approximately 15-minute intervals from near sunrise until just after solar noon. Test variables recorded during the array rating on 9/24/95 included the following ranges:

POA Irradiance:

Ambient Temperature

230 to $1200 \mathrm{~W} / \mathrm{m}^{2}$

Array Temperature

Wind Speed

Solar Angle-of-Incidence

Absolute Air Mass

15 to $25^{\circ} \mathrm{C}$

19 to $50^{\circ} \mathrm{C}$

2 to $5 \mathrm{~m} / \mathrm{s}$

75 to 2 degrees

3.7 to 0.95

Figures 3-6 illustrate the Sandia method applied to measured I-V data from the array. The parameters $I_{s c o}, I_{m p o}$, $V_{\text {oco }}, V_{\text {mpo }}$ give array performance at the reference operat- ing condition. Temperature coefficients were applied to all measured parameters to translate them to the reference temperature. The "AMa-Function" and the "AOlFunction" were used in the determination of $I_{\text {sco. }}$. The "effective irradiance," $E_{e}$, was defined as the ratio of measured $I_{s c}$ at $T_{c}=50^{\circ} \mathrm{C}$ divided by $I_{s c o}$; thus, equal to 1 at the reference operating condition. The procedure resulted in array performance defined by three well behaved linear relationships giving $\mathrm{I}_{\mathrm{sc}}, \mathrm{I}_{\mathrm{mp}}$, and $\mathrm{V}_{\mathrm{oc}}$, and one polynomial fit for $V_{\text {mp. }}$

\section{ARRAY PERFORMANCE MODEL}

The array performance model developed by Sandia is given by Equations 1-4. The accuracy of this performance model is illustrated by Fig. 7 . The power rating for the Carol Spring Mountain array at ASTM standard reporting conditions [1] was determined to be $25.3 \pm 0.8 \mathrm{~kW}$. This result agreed well with the performance specification (25.6 kW). APS can now accurately monitor system performance by comparing predicted power output to measured values continuously recorded at the site.

$I_{s c}\left(E_{e}, T_{c}\right)=E_{e}\left\{I_{s c 0}+\alpha_{s c}\left(T_{c}-50\right)\right\}$

$I_{m p}\left(E_{e}, T_{c}\right)=C_{1}+E_{e}\left\{C_{2}+\alpha_{i m p}\left(T_{c}-50\right)\right\}$

$V_{o c}\left(E_{e}, T_{c}\right)=V_{o c o}+C_{4} \ln \left(E_{e}\right)+\beta_{\text {Voc }}\left(T_{c}-50\right)$

$V_{m p}\left(E_{e}, T_{c}\right)=V_{m p o}+C_{6} \ln \left(E_{e}\right)+C_{7}\left\{\ln \left(E_{e}\right)\right\}^{2}+$

Where:

$$
\beta_{V m p}\left(T_{c}-50\right)
$$

$E=$ Measured POA irradiance, $\mathrm{W} / \mathrm{m}^{2}$

$E_{e}=(E / 1000) f_{1}\left(A M_{a}\right) f_{2}(A O I)$

$I_{s c o}=I_{s c}\left(1000 \mathrm{~W} / \mathrm{m}^{2}, A M a=1.5, T_{c}=50^{\circ} \mathrm{C}, \mathrm{AOI}=0^{\circ}\right)$

$I_{m p o}=I_{m p}\left(T_{c}=50^{\circ} \mathrm{C}, E_{e}=1\right)$

$V_{\text {oco }}=V_{o c}\left(T_{c}=50^{\circ} \mathrm{C}, E_{e}=1\right)$

$V_{m p o}=V_{m p}\left(T_{c}=50^{\circ} \mathrm{C}, E_{e}=1\right)$

$\alpha_{\mathrm{Isc}}=\mathrm{I}_{\mathrm{sc}}$ temperature coefficient, $\left(\mathrm{A}^{\circ} \mathrm{C}\right)$

$\alpha_{\mathrm{Imp}}=I_{\mathrm{mp}}$ temperature coefficient, $\left(\mathrm{A} /{ }^{\circ} \mathrm{C}\right)$

$\beta_{V o c}=V_{o c}$ temperature coefficient, $\left(V^{\circ}{ }^{\circ} \mathrm{C}\right)$

$\beta_{\mathrm{Vmp}}=V_{\mathrm{mp}}$ temperature coefficient, $\left(\mathrm{V} /{ }^{\circ} \mathrm{C}\right)$

$\mathrm{C}_{1}, \mathrm{C}_{2}=$ Regression coefficients for Imp, $\mathrm{C}_{1}=0$ typical

$\mathrm{C}_{4}=$ Regression coefficient for $\mathrm{V}_{\mathrm{OC}}$

$C_{6}, C_{7}=$ Regression coefficients for $V_{m p}$

$\mathrm{AM}_{\mathrm{a}}=$ Absolute air mass

$\mathrm{T}_{\mathrm{c}}=$ Calculated cell temperature $\left({ }^{\circ} \mathrm{C}\right)$

$f_{1}\left(A M_{a}\right)=$ "AMa-Function"

$\mathrm{f}_{2}(\mathrm{AOI})=$ "AOI-Function"

\section{CONCLUSIONS}

The new and innovative performance characterization methodology described in this paper will enable the photovoltaic industry and its customers to accurately determine the performance of any array at any location. This ability should help promote harmony among those involved in the procurement, rating, and/or use of photovoltaic modules and arrays. In short, it will facilitate the commercialization of photovoltaic technologies.

\section{ACKNOWLEDGMENTS}

The authors would like to acknowledge valuable support and comments from the following people: Abraham Ellis and Steve Durand (SWTDI), Chuck Whitaker 
(ENDECON), Moneer Azzam (ASE Americas), Allen Gunn (SEI), John Wohlgemuth (Solarex), Jim Rand (AstroPower), Tim Ball (APC), Clin Lashway (Raydec); and Jay Kratochvil, Bill Boyson, Mike Thomas, Rick Chapman, Alex Maish, and John Stevens (Sandia).

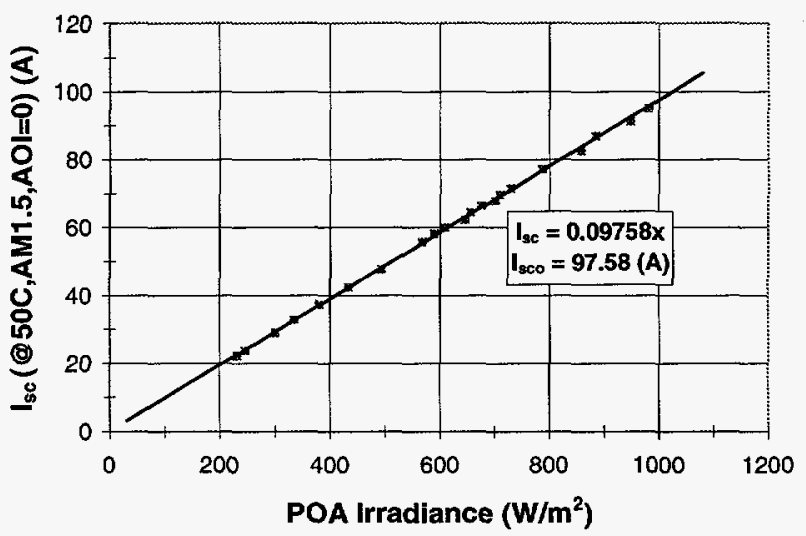

Fig. 3. Measured $I_{s c}$ with $A M a$ and $A O I$ effects removed.

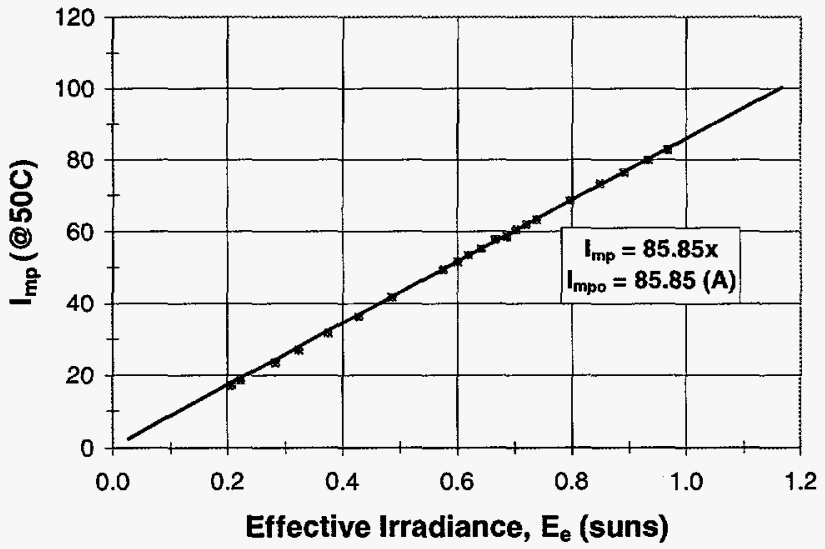

Fig. 4. Measured I $\mathrm{mp}_{\mathrm{p}}$ related to "effective" irradiance.

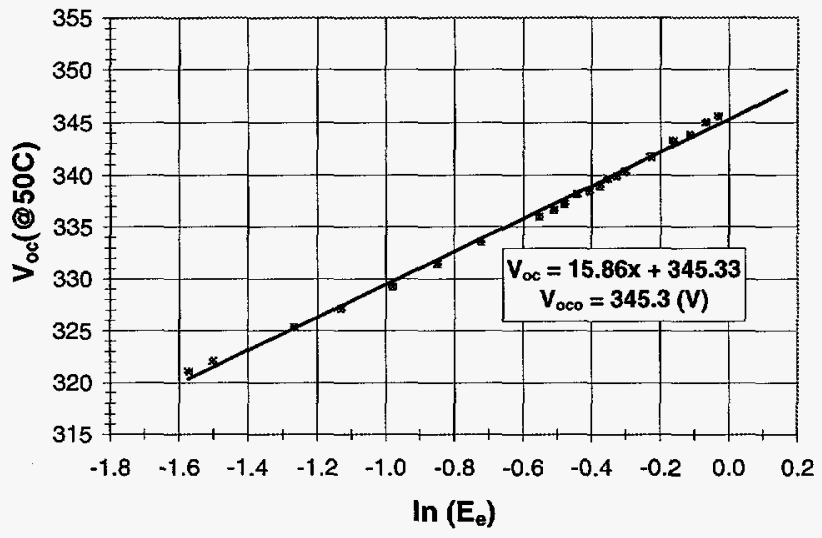

Fig. 5. Measured $V_{o c}$ related to "effective" irradiance.

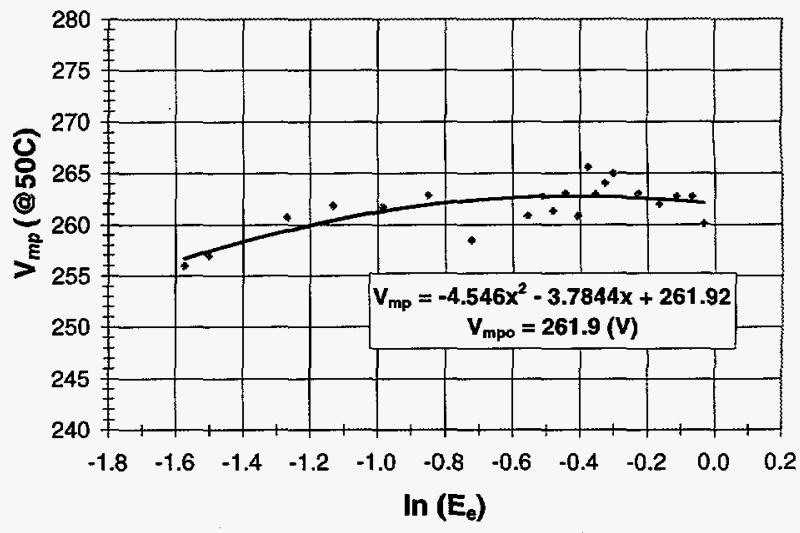

Fig. 6. Measured $V_{m p}$ related to "effective" irradiance.

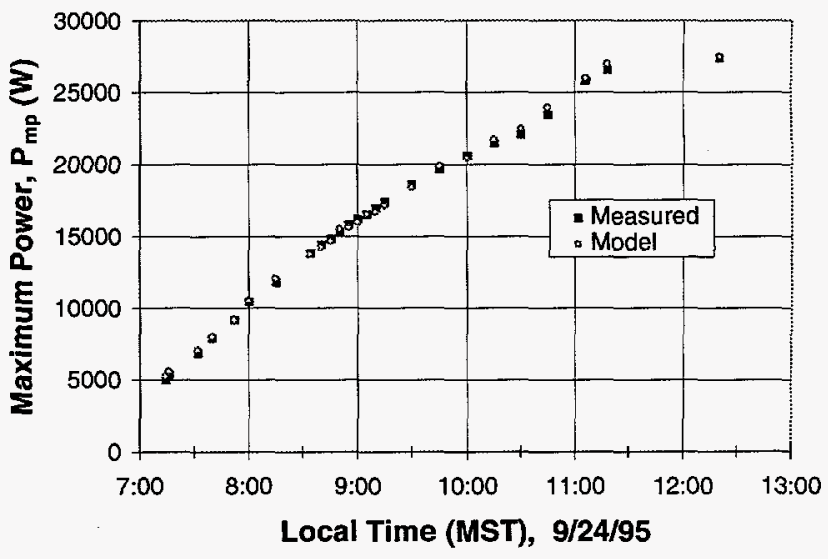

Fig. 7. Measured $P_{m p}$ compared to predictive model

\section{REFERENCES}

1. ASTM E-1036, "Standard Methods for Testing Electrical Performance of Nonconcentrator Terrestrial PV Modules and Arrays Using Reference Cells."

2. T. Candelario, et al, "PVUSA - Performance, Experience, and Cost," 22nd IEEE PVSC, 493-500, 1991.

3. M. Bergman, et al, "Implementation of the U.S. Utility Industry's TEAM-UP Commercialization Initiative," 24th IEEE PVSC Proceedings, pp. 2341-2344, 1994.

4. T. Townsend, et al, "A New Performance Index for PV System Analysis," 24th IEEE PVSC,1036-1039, 1994.

5. A. Rosenthal, M. Thomas, and S. Durand, "A Ten Year Review of Performance of Photovoltaic Systems," 23rd IEEE PVSC, pp. 1289-1291, 1993.

6. I. Zanesco and A. Krenzinger, "The Effects of Atmospheric Parameters on the Global Solar Irradiance and on the Current from a Silicon Solar Cell," Progress in Photovoltaics, Vol. 1, pp. 169-179, 1993.

7. F. Kasten and A. Young, Applied Optics, 28, 47354738 (1989).

8. R. L. Hulstrom, Solar Resources, MIT Press, 1989.

9. M. S. Imamura, et al, "Assessment of Simplified Outdoor Calibration Methods for Solar Irradiance Sensors," 11th European PSEC, pp. 1638-1643, 1992. 


\section{DISCLAIMER}

This report was prepared as an account of work sponsored by an agency of the United States Government. Neither the United States Government nor any agency thereof, nor any of their employees, makes any warranty, express or implied, or assumes any legal liability or responsibility for the accuracy, completeness, or usefulness of any information, apparatus, product, or process disclosed, or represents that its use would not infringe privately owned rights. Reference herein to any specific commercial product, process, or service by trade name, trademark, manufacturer, or otherwise does not necessarily constitute or imply its endorsement, recommendation, or favoring by the United States Government or any agency thereof. The views and opinions of authors expressed herein do not necessarily state or reflect those of the United States Government or any agency thereof. 